\title{
THE INFLUENCE OF COVID-19 IN THE DANGER THAT POPULISM BRINGS TO THE SECURITY ENVIRONMENT
}

\author{
Dorin Alin Gal ${ }^{1}$ \\ "Carol I" National Defence University
}

\begin{abstract}
Populism has become, for quite some time now, a specter of democracy that threatens the structure of security wherever it shows up in situations that thoroughly fight democracy's fundamental values. The COVID-19 pandemic has changed what citizens think and the expectations that they have from those in power, so populism has also been affected through the relationship that it has with the people's level of satisfaction. This process requires a thorough analysis due to the threats that can appear from such leaders in a world that is still trying to find itself.
\end{abstract}

Keywords: populism; covid-19; post-pandemic threats.

\section{INTRODUCTION}

Populists are known for their ability to extend along the whole political spectrum and to adapt their ideas in order to survive any type of speech. Despite the support that populist leaders claim to have from modern-day citizens attracted to what they propose, these leaders have always operated by using a classic definition of "the people". Jan-Werner Muller, the famed author, clearly describes the behavior that populists are trying to get from their followers:

He defines this process as "a way of perceiving the political world in which a morally pure and completely unified 'people' - but ultimately fictional, I would add - is set against the elites that are considered corrupt, or in any other way morally inferior (Muller 2016, pp. 19-20)

At the same time, Muller rejects the idea that populists are doomed to failure once they are in power, a notion that makes them evidently more dangerous. Even if this ideology is based on two main ideas, anti-elitism and anti-pluralism, it has an enormous capability to adapt in the spur of the moment. Populist parties argue against the elites, but their speech changes radically once they become part of the government. From that moment on, all the positive results will be attributed to the success of the populist leaders, while any failures will continue to be the wrongdoing of the same elites. Muller argues that the illusion based on the sudden disappearance of populists once they are in power is a mere political maneuver: "Populists always distinguish morally between those who properly belong and those who don't (even if that moral criterion might ultimately be nothing more than a form of identity politics)" (Muller 2016, 80)

The COVID-19 pandemic has hit the whole world in a very diversified way and has become an element that needs to be accounted for when trying to observe the populist mark in the world. With the emergence of populism as one of the more potent forces of today, a thorough analysis on the impact that COVID-19 has had on the ideology and its 'people' is necessary if we want to be able to understand and contain the security threats of today and tomorrow.

\section{METHODOLOGY}

COVID-19 has led to the attention of the citizens focusing a lot more on the measures that their leaders had in store in order to see what kind of life-saving decision they can make in a very serious and real context. The relatively low level of confidence that people had in the governing ability of the "elites" was a general problem and, in such a scenario, the emergence of a populist actor is always a possibility.

\footnotetext{
${ }^{1}$ Corresponding author: doringal07@gmail.com
} 
Even if the wide-area implications of the virus have to be analyzed using comparative studies in many countries, the purpose of this paper is not to analyze the way in which different parts of the world have responded and will respond to populism during the pandemic. Rather, we want to track the social changes that can affect the way in which this ideology is regarded by the citizens, but also the impact that the new status quo can have on security.

For this, we are going to use the works of exponential authors when it comes to understanding populism such as Muller, Mudde and Canovan. Furthermore, we're also going to use articles of known representatives of the international press such as The Guardian and The Conversation who have closely followed the reactions of the people during the early days of the pandemic. Last but not least, we will draw on the work of Ulrike Vieten in order to have a working guide for the image that we aim to present here. In her work, "The 'New Normal' and 'Pandemic Populism": The COVID-19 Crisis and Anti-Hygienic Mobilization of the Far-Right", professor Vieten offers a fresh perspective on the change that the populist perception can go through due to the effects of the pandemic and the normalization of the global far-right (Vieten 2020, 2).

Francis Fukuyama outlined that "populism, most of the time, implies a politician that pretends to have direct and charismatic links to the people, something that grants him a special type of claim in following the people's interests (De Witte 2019). Since a recession period is almost impossible to avoid due to the economic shock of the pandemic, and countries were having problems in the relationship with their citizens even before that, the question that we ask is obvious: Will populism rise even more in these circumstances? Will the global context evolve into something new, very close to a modern type of social anarchy, or will the people stand behind their governments in this new era?

In other words, what we aim to see is if the populist message is still popular in the face of a serious, real threat. Do the people support it simply as a way to somehow get back at their government, or do they see it as an actual possibility of leadership replacement? Furthermore, another very interesting question can be raised on the reaction of different populist actors: Did populist adepts have a unitary reaction to the effects of the pandemic, or have they adapted due to the characteristics of each country's situation?

\section{POPULISM: A VIRUS HIT BY THE COVID-19 CRISIS}

The populist leader does not base his power simply on the calls he makes towards the failures of the state, but he also identifies as one of the people, using a speech in which he always manages to find threats to the entire nation. The COVID-19 pandemic has emerged by spreading fear at a global level due to the necessity of imposing social and economic restrictions. Therefore, society was forced to undergo changes that also had an impact on the moral values of the citizens, thus changing the way in which populism can appeal to them.

As Margaret Canovan stated, the populist democracy aims to provide substance to the idealist notion of "people governance" using one of the forms of direct democracy, several times aiming towards a referendum, popular initiatives and organizational procedures (Canovan 1981, 137). Therefore, populism is not a "kamikaze" of political ideas that has the single purpose of getting to power so that it can then vanish among the classic ideologies. Such leaders that manage to get in power continue to govern in the way that brought them there, even showing a tendency for becoming more radical as time goes on.

Due to the effects of the pandemic, populists can therefore represent a certain danger not only through their amplified potential of radicalizing the entire population, but also through their flat refusal of leaving power when asked to do so. A small-scale study that was conducted in April 2020 has shown an almost immediate loss of citizens' trust for the governments of Great Britain and the United States due to the lack of an immediate and effective answer to the requirements of the pandemic (Strandberg, 2020).

Similarly, the way former American president Donald Trump has incited his followers to attack the Capitol on the very same day that Joe Biden was due to be formally recognized in Congress does nothing but prove the lengths that populists are willing to go to in order to ensure their stay in power (Beaumont et al. 2021). 
Therefore, it becomes obvious that we need to analyze the way in which populism has changed during the COVID-19 pandemic in order to identify the potential of future support for such leaders, as well as observe certain dangers that could present themselves in the short and mediumterm.

Cas Mudde has emerged as one of the more sober analysts of populism from the beginning of the pandemic. While most observers were quick to point out (and rightfully so) that a lot of countries were falling in behind their leaders, the Dutch politologist had a much more rational approach. Mudde explained that populism, an extremely diverse and volatile phenomenon, cannot bring a unified, global response to the pandemic (Mudde 2020). Due to the risks, he identified that need for each individual situation to be evaluated on its own.

\section{The populist threat în the pandemic. "The new normal"}

The pandemic has transformed the need for truth felt by the general population, making this right completely essential in order for the citizens to feel that they are being protected. Populism works by distorting this reality and using its less-positive aspects in order to construct the image it needs to acquire social capital or power. Therefore, even though general support for populist leaders seems to have dropped down in the first year of the pandemic (McCaffrey, 2020), the long-term effects of the quarantine still remain a viable threat.

Hannah Arendt underlined that the essential element of totalitarian tendencies was their need of controlling the masses, as opposed to similar political movements that aim to remove or eliminate their opposition. When it comes to the actual threat, Arendt drew a line between the danger represented by such forms of leadership and the ability of citizens to understand and filter true and false information (Arendt 1953, 321).

When analyzing the current reality, the context seems to be perfect for populist actors who want to try and engage in such manipulation, while also being protected by the ideological umbrella of democracy. During the coronavirus, the best-known populists have overwhelmingly positioned themselves against protective measures, even though it is hard to understand whether this choice was made through some type of reasoning, or simply in order to be against the criticized elites. On the other hand, not all of them have done so and this is yet another testament to the difficulty of understanding and combating populism.

Prominent leaders such as Donald Trump of the United States and Jair Bolsonaro of Brazil have chosen the skeptical approach and tried to downplay the crisis, while Viktor Orban of Hungary and Andrej Babis of the Czech Republic have imposed severe lockdown measures. The speech of "us versus them" finds numerous supporters today due to the plethora of conspiracy theories and the promotional capacity offered by social media. When the public sees a picture in which it can only find friends and enemies, the consequences can always be dangerous.

Furthermore, populists have the distinct advantage of not being exposed to the same type of risk that other actors would if they were to be promoting extreme measures because they claim to do everything "for the people", even if in practice they sometimes compromise and enter coalitions as well (Muller 2016, 37). Therefore, Vieten argues that the leading question we should be asking ourselves right now should be to find out if or how much the pandemic has blurred the lines between mainstream political mobilization (some of which is to be expected in the face of restrictions) and activities of the extremist and racist far right (Vieten 2020, 3).

Seeing how new information on this pandemic continues to emerge as the world is dealing with the crisis, the context does not provide many ways through which said information can be verified. Uncertainty is the engine of populist expansion. Confronted with a lack of clear solutions and information, the public may very well turn towards the pompous speeches of a populist leader at some point in time.

Therefore, we argue that the difference will be best seen in the amount of data and evidence that actors will be able to provide for the policies that they propose. Since populists tend to dismiss empirical data and rely on their own opinion, the demagogy of such a leader will always try to use COVID-19 as a source of unchallenged, unverified accusations that cannot be effectively fought-off 
due to lack of evidence. Spreading such discourses was one of the main ways in which Donald Trump was able to get into the most powerful office on Earth for four years. Through this type of modus operandi, the American politician was able to not only blame the conservative tendency against sudden changes, but also point the finger towards the new type of policy being conducted on online platforms such as Twitter (Richardson 2017, pp.5-6).

Even worse, preliminary findings suggest that, regardless of the difference in answers across the populist board, there is a variety of irresponsible and faulty approaches when it comes to how populist leaders and governments dealt with COVID-19 (Stavrakakis, Katsambekis 2020, 3). Therefore, while support for such actors seems to have dropped down since the beginning of the pandemic, its consequences can have the potential to breed even more populist leaders, so expecting the pandemic to signify the beginning of the end for far-right populism is a little premature at this point in time.

During the pandemic, populist leaders have drawn on their volatile nature and engaged in various forms of offering answers. Even if some of them took COVID-19 seriously, the scope and duration of their measures is another changeable element. For instance, Hungary adopted a bill that granted its leaders emergency power in order to deal with the pandemic head-on (Meyer 2020, 5). India and Algeria's leaders, on the other hand, took advantage of the newfound legitimacy when it comes to banning meetings to conveniently remove the protesters in their streets. On the other end of the scale we have former US president Donald Trump's approach who repeatedly claimed the virus will go away once the heat comes, and even accused his Democrat opponents of lying about it in order to bolster their poll results (Beer, 2020).

The advantage is that populists always use a real or fictional crisis as a way to oppose any other narratives that are present at some point in time, an approach that will almost always lead to conflict. Seeing how we are facing arguably one of the more challenging periods in modern history, the danger of populism is too relevant to be ignored.

\section{Post-pandemic populism: How it can shape the security environment}

It is precisely this diversity in reactions that allows us to come up with a clear argument regarding the future threats that can emerge from populism. It has become obvious that trying to perceive the policies of certain actors strictly through a populist lens is an exercise in futility. Even if we are still adapting and understanding the new status quo generated by the pandemic, we should still be able to draw conclusions regarding the way that populism will behave in the future.

The study of cases such as the one in Hungary has shown the necessity of an approach that can fight back against the thin ideological center of this idea and the danger it poses since it can embrace the characteristics of any of the problems found in the society it exists in (Urbinati 2020).

Notions like nationalism and nativism cannot be forgotten from such an analysis in order to guarantee its results. The COVID-19 pandemic is the first case study that has shown local differences in populist approaches, so the security environment must avoid using fixed strategies when fighting this threat. For instance, Donald Trump has, on multiple occasions, described the new coronavirus as "the Chinese virus", fueling the racist, anti-immigrant feelings that were already more than present in the United States (Stavrakakis, Katsambekis 2020, 7)The specter of populist threats has increased during the pandemic, despite their reduced power of impact. The threat is, therefore, still present and maybe more complex than ever before.

Second of all, can we speak about the risks of a new wave of populist support once the world reaches some type of normal? Seeing how populism is an extremely complex and representative democracy-dependent phenomenon, the answer will be that this depends on the way things are going to go in the next months and years.

The way in which national governments and international organizations will tackle the long road to recovery will either lead to a fresh wave of populist legitimacy, or to a fresh wave of diminished populist effects.

Here, we deem necessary to aim for a distinction between what we will call, for lack of better terms, "good populism" and "bad populism". There are certain ideas that can be found in almost any 
analysis of this ideology: anti-elitism, anti-institutionalism, plebiscitary tendencies, and a certain appeal towards "revisionist" attitudes and all-out attacks towards their opponents. When it comes to the pandemic, different leaders have tackled different approaches, all of them consistent with the way they managed to get in power.

For instance, leaders like Narendra Modi of India and Viktor Orban of Hungary have used the crisis to further enhance the internal cultural conflict which helped them win their seat (Meyer 2020, 7). On the other hand, Geert Wilders and his Party for Freedom in Netherlands have their main focus on the issue of Islam (Damhuis 2019) and have asked for tighter restrictions from the beginning of the pandemic.

From this, we can draw that populists will continue to follow their own creed regardless of the security environment, and this means that they won't always be a danger to it. However, we should bear in mind that COVID-19 is a rather exceptional situation that will not always happen to be outside a populist's area of interest. This does mean, though, that such actors don't necessarily have a love for anarchy, but simply choose to follow their political objectives no matter the cost to others.

We should also remember that, in recent years, many political scholars suggested that in order to weaken populism, democracies will have to curtail some aspects of their politics (Urbinati 2020). Now, with the pandemic forcing even constitutional democracies to adopt measures that are strikingly out of character, populism may have a leg to stand on in the long run once again.

The limitations and challenges of democracy that have led to the populist ascension are still present in the pandemic and will still be there when it's over. Different actors will continue to see populism in different shapes ranging from a threat to a potential cure for modern, Westernized democracy. Regardless of personal opinions, its ambiguous and volatile nature makes sure that the risks that were there before COVID-19 took over the world are still a part of the structure of the international political life. Furthermore, the "patriotic" populist speech grows even more significant during national lockdowns and movement restrictions, something that Vieten calls "the global return to the local" (Vieten 2020, 4).

More and more people getting vaccinated certainly shows a step in the right direction. However, a return to complete normalcy is still a long way ahead and, as citizens become more and more tired of restrictions, we could see a surge in populist supporters because they claim to speak in the name of the whole "people". While Muller warns against this behavior by arguing that "the idea of a single, homogenous, authentic people is a fantasy" (Muller 2016, 3) the support shown to the authorities by their citizens at the beginning of the pandemic may start to fade it this situation becomes increasingly drawn-out.

\section{CONCLUSIONS}

Populism will keep being dangerous for the security environment even after the COVID-19 pandemic is over. When it comes to such leaders, the behavior of certain actors or the political differences are not what's important. Rather, they focus on establishing normative differences between the people they claim to be working for and the elites of the state.

It is our opinion that COVID-19 was a milestone for populism from two points of view: first, it tested the reaction of the people in the face of a very real threat, something which had not happened for quite some time. Second, it challenges the evolution of modern democracies because the pandemic has the potential to set up more fertile ground for even more populist actors, so authorities need to be able to contain this phenomenon.

The post-COVID-19 period will be extremely important for the type of support that we should expect to see populism receiving in the future. If citizens will continue to blame a lack of transparency and dialogue, the emergence of certain actors that will claim to be representing and unifying the problems of the society against the political elites may even be a good thing for modern democracies, assuming such actors can actually show up.

On the other hand, the difference between "good populism" and "bad populism" merely underlines the approach during this particular moment, without considering the fact that the problems 
that may end up happening due to it can also lead to social tensions which, in the long run, may be problematic and not even remotely connected to their origin.

Therefore, it is essential that the security environment is able to maintain the analytical skepticism with which it has been observing populism lately. Identifying the short-term threats brought by the pandemic definitely represents a priority, but we must not ignore the ways in which these consequences can fuel the future emergence of new populist leaders. The COVID-19 virus has brought forward, even in the most prominent of democracies, the necessity for temporary bans on certain rights and freedoms. While populism has slowed down a bit during the pandemic, this need may end up fueling it even more in the long run. Seeing how this is an ongoing context, citizens may understand it in different ways and this might lead to unrest and confusion. Due to this, we are facing a double-edged sword of responsibility: Leaders need to take action in order to mend the communication channels with their own people, while the security environment needs to employ its early warning capabilities in order to learn from the lessons of 2016. If not, we can be certain that populism, this morally-self-satisfied version of politics, will always be able to use the lack of substance for its own gains.

\section{REFERENCES}

Arendt, Hannah. 1953. "Ideology and Terror: A novel form of governance". The Review of Politics 15. 303-327.

Beaumont, Peter, et al. 2021. How a mob of Trump supporters stormed the Capitol - visual guide. Accesed March 7, 2021. https://www.theguardian.com/us-news/2021/jan/07/how-a-mob-oftrump-supporters-stormed-the-capitol-visual-guide

Beer, Tommy. 2020. Trump Predicted 'Covid, Covid, Covid?' Would End After The Election. It's worse than ever. Accesed March 8, 2021. https://www.forbes.com/sites/tommybeer/2020/11/11/trumppredicted-covid-covid-covid-would-end-after-the-election-its-worse-thanever/?sh=630399976512.

Damhuis, Kohen. 2019. Why Dutch populists are exceptional: A 'Muslims in the West' reaction essay. Accesed March 10, 2021. https://www.brookings.edu/articles/why-dutch-populists-areexceptional/.

De Witte, Melissa. 2019. How the Great Recession Infuenced Today's Populist Movements. Accessed March 3, 2021. https://www.gsb.stanford.edu/insights/how-great-recession-influenced-todayspopulist-movements.

Katsambekis, Stavrakakis. 2020. Populism and the pandemic: A collaborative report. Loughborough University.

Margaret, Canovan, 1981. Populism. New York: Harcourt Brace Jovanovich.

McCaffrey, Darren. 2020. Analysis: Will Covid-19 usher in a new wave of populism in Europe?. Accessed March 2, 2021. https://www.euronews.com/2020/06/05/analysis-will-covid-19-usherin-a-new-wave-of-populism-in-europe.

Meyer, Brett. 2020. Pandemic Populism: An Analysis of Populist Leaders' Responses to Covid-19. Tony Blair Institute for Global Change.

Mudde, Cas. 2020. Will the coronavirus 'kill populism?' Don't count on it. Accesed March 10, 2021. https://www.theguardian.com/commentisfree/2020/mar/27/coronavirus-populism-trump-politicsresponse.

Muller, Jan-Werner. 2016. What is Populism?. Unniversity of Pennsylvania Press.

Richardson, Michael. 2017. "The disgust of Donald Trump". Continuum 31, no. 6. 747-756. 
Strandberg, Thomas. 2020. Coronavirus: US and UK governments losing trust. Accessed March 2, 2021. https://theconversation.com/coronavirus-us-and-uk-governments-losing-public-trust-137713.

Ulrike, Vieten. 2020. "The 'New Normal' and 'Pandemic Populism': The COVID-19 Crisis and AntiHygienic Mobilisation of the Far-Right". Social Sciences 9, no. 9. 165.

Urbinati, Nadia. 2020. The Pandemic Hasn't Killed Populism. Accessed March 12, 2021. https://www.foreignaffairs.com/articles/united-states/2020-08-06/pandemic-hasnt-killedpopulism. 